University of Rhode Island

DigitalCommons@URI

Open Access Master's Theses

1994

\title{
The Consequences of Gambling on Indian Reservations
}

Jeffrey L. Pegram

University of Rhode Island

Follow this and additional works at: https://digitalcommons.uri.edu/theses

Recommended Citation

Pegram, Jeffrey L., "The Consequences of Gambling on Indian Reservations" (1994). Open Access

Master's Theses. Paper 600.

https://digitalcommons.uri.edu/theses/600

This Thesis is brought to you for free and open access by DigitalCommons@URI. It has been accepted for inclusion in Open Access Master's Theses by an authorized administrator of DigitalCommons@URI. For more information, please contact digitalcommons-group@uri.edu. 



\section{U.R. LERPARY SPECIAL COLLETIONS}

MASTER OF ARTS THESIS

$\mathrm{OF}$

JEFFREY L PEGRAM

APPROVED :

Thesis Committee

Major Professor

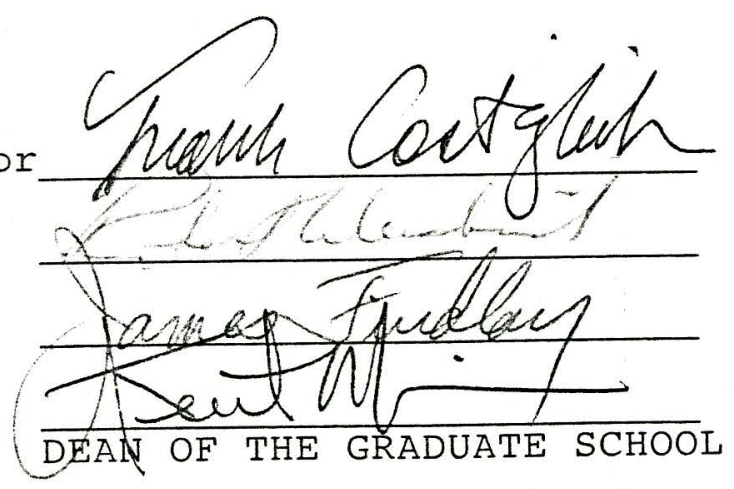

UNIVERSITY OF RHODE ISLAND

1994 


\section{U.R.I. LIBRAPY

ABSTRACT

There are many issues and debates related to Indian

casinos. However, there are very few well researched studies on the impact of Indian gaming. Through the use of books, magazines, newspapers, and interviews, I was able to find out the effects of gambling casinos on some Indian tribes. I traveled to several reservations in the United states that have casinos and some that did not. I conducted interviews with several Indian people to see how they felt about casino gambling on reservations. The results that I came up with were overwhelmingly in favor of casinos on reservations. Many reservations that were once in poverty have had a chance at a better life because of casinos. My paper will discuss how casinos have helped to create financial stability on many reservations across the country and how tribes have a reason to be hopeful for the future. 


\section{ACKNOWLEDGEMENTS}

I would first of all like to thank Dr. Morton Briggs of the University of Rhode Island for getting me started in History. His knowledge and enthusiasm for the subject started me on the right path. He is an excellent teacher as well as historian. I know only too well how difficult a job that is.

I would like to thank my Major Professor, Dr. Frank Costigliola for his constant encouragment to finish this project. Our many discussions on the topic made the job that much easier. His advice was always taken to heart, if not always acted upon right away.

Special thanks go to the Dean of the Graduate School, Kent Morrisson. He believed in me and always offered his assistance to help me in any way that he could.

I would like to thank Nancy Brown-Garcia for all of her help and encouragement.

This work is dedicated to my parents, Philip o. Pegram and Cheryle A. Pegram, who have supported and put up with me for so long. 


\section{U.R.I. LIBRARY SPECIAL COLLECTIONS}

TABLE OF CONTENTS

page

Introduction..........................

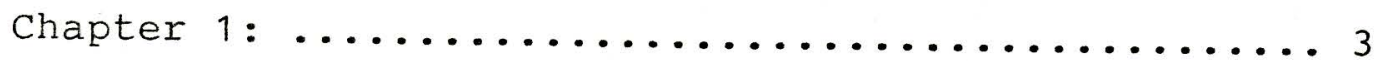

Chapter $2: \ldots \ldots \ldots \ldots \ldots \ldots \ldots \ldots \ldots \ldots \ldots \ldots \ldots \ldots \ldots \ldots \ldots \ldots \ldots \ldots \ldots$

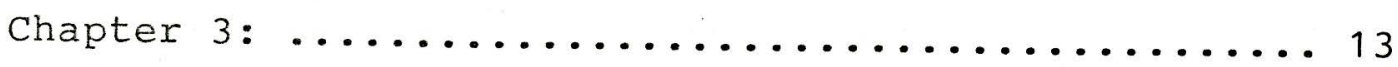

Chapter $4: \ldots \ldots \ldots \ldots \ldots \ldots \ldots \ldots \ldots \ldots \ldots \ldots \ldots \ldots \ldots$

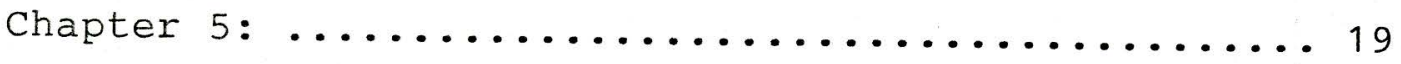

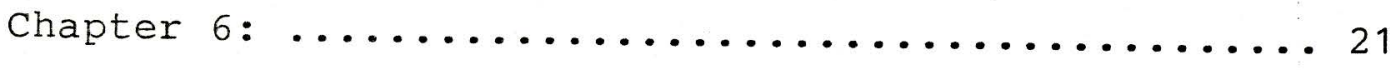

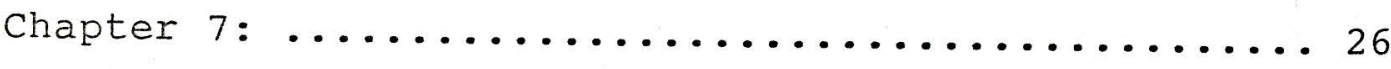

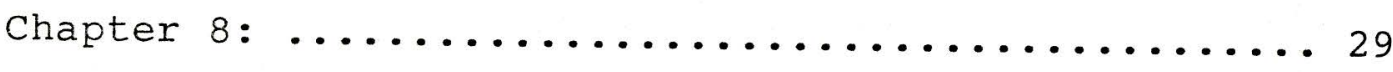

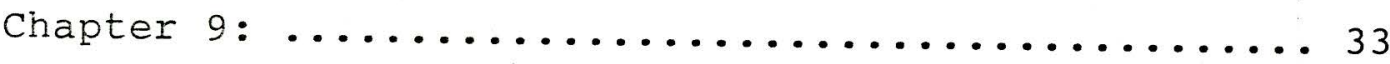

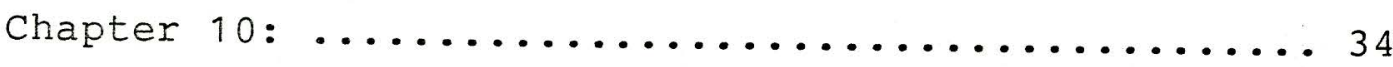

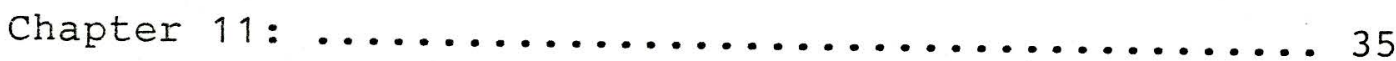

Endnotes..............................4 40

Bibliography.......................... 44 


\section{U.R.I. LIBRAAY SPECIAL COLLECTIONS}

THESIS

There are many issues and problems related to Indian casinos in the early 1990s. Unfortunately, there are few well researched studies on the long-term effects of gambling casinos on reservations. This paper will delve into the effects that casino gambling have on Indian tribes. The biggest issues facing tribes with casinos today are tribal jurisdiction, casino compacts, and administrative financial policies. Other issues include federal policies that undermine tribal policy and jurisdiction. An example of this is, state Troopers have jurisdiction on some Indian lands where casinos are located. Indian casinos on reservations have proven to have positive impacts within Indian communities across the country as well as non-Indian communities. Many business outside of the reservations have benefited with the influx of people going to the casinos. Indians were aware that huge amounts of money could be made, under the provisions of Federal Law as required in the 25 United States Code, Sections 2701 et seq., the (Indian Gaming Regulatory Act of 1988). Where and how was the money spent? The money was spent on community development on reservations and Indian housing. The money also created jobs for Indians and non-Indians. Did Indian people get their fair share of their casino proceeds? Tribal members were given checks from their casinos periodically to help pay their bills. Were Indian people actually running their 



\section{BACKGROUND}

Many tribes have fought to have Indian casinos on their lands. The issue of the Narragansetts struggle has been well researched.

In 1880, the Rhode Island General Assembly bought the last 922 acres owned by the Narragansett Tribe for $\$ 5000$ and passed legislation with federal approval that ended the tribe's legal existence. Three hundred twenty four Narragansett men, women, and children got $\$ 15.43$ each. Only two acres around the Narragansett Indian Church remained in tribal hands. 1

In 1975, the tribe sued the state of Rhode Island and private land owners on the grounds that the 1880 and other land acquisitions violated a 1790 federal law which said only the federal government can authorize and approve sales of Indian lands, and terminate a tribes existence.

By 1978, the tribe, the federal government and the state settled out of court. The tribe agreed to drop its claims on the 3200 acres in the town of Charlestown in exchange for 1800 acres of land. Approximately 900 acres of that was to be provided without a fee, by the state of Rhode Island and another 900 acres was to be purchased by the federal government from private landowners ok. legislation. The tribes agreed to a joint memorandum of understanding that the federal legislation that was to be enacted gave the state of Rhode Island the authority 


\section{U.R.I. LBRAAYY SPECIAL COLLECTIONS}

to enact its own legislation to create a state chartered corporation that had perpetual interest in the land. This legislation is codified as 25 UsC1701-1715.2

In 1983, the United States Government recognized the Narragansetts as an "Indian tribe."

In 1988, Congress passed the Indian Gaming Regulatory Act, (IGRA) Senate Bill 555, pemitting Indian casinos on tribal lands. This law was irplemented because states were trying to control Indian casinos. An example of this, was the the Cabazon Mission Banc of Indians vs. the state of California. The state of California tried to take control and say that it had powes over the Cabazon Indian casino. However, by law the state had no authority over the casino unless otherwise stated by Congress. Therefore, (IGRA) was passed so that the feleral government, not the state governments, could reclate Indian gaming. During the floor debate on Senate Bill 55, at 134 Congressional Record 12,649 and 12,650 (daily edition september 15, 1988), Senators Clairborne Pell nd John Chafee, of Rhode Island, in exchange for dropping language in senate Bill 555, specifically exempting the arragansett Indian Tribe or other land settlement tribes, got a verbal assurance from Senator Daniel Inouye, Chai man of the Senate Select Committee on Indian Affairs, that "protetions of the Rhode Island Claims Settlement Act (P.L. 95-395) cited at 25 United States Code 1701 to 1715 and specifically on jurisdictional matters at 1708 , will renain in effect 
and that the Narragansett Indian Tribe clearly will remain

subject to the civil, criminal and regulatory laws of

the state of Rhode Island."3

on July 15, 1992 the Narragansetts said that the 1988 Indian Gaming Regulatory Act nullified the 1978 settlement agreement concerning casinos, and notified Governor Bruce sundlun that they planned to build a casino. The tribe asserted that under the 1988 Act, it was not bound by state and town laws. The state filed a federal lawsuit to stop the tribe, declaring that the settlement Act meant that state law, not (IGRA), applies.

It took a year before senior U.S. District Judge Raymond J. Pettine ruled for the Narragansetts, but stayed his decision pending an appeal. On April 2, 1993, the state appealed to the U.S. Appeals Court in Boston on grounds of jurisdiction.

Finally, on March 23, 1994, the appeals court ruled two to one that the tribe had the right to build a casino. The appeals court rejected the state's claim, ruling that Congress clearly intended to give Indian tribes the right to operate casinos.

While siding with the Narragansetts on the casino, the appeals court rejected the tribe's claim that, as a sovereign nation, they had absolute power over their land. The court ruled that the state can exert some authority over non- gambling facilities on tribal land, such as hotels and parking lots. The appeals court ruling 
granting limited regulatory authority was an unexpected victory. Elizabeth Murdock Myers, a lawyer who handled the case for the state, said to her knowledge it was the first time a state had been granted some civil regulatory jurisdiction on tribal land.

Tribes do not have absolute power on their reservations because state Police have the right to come on Indian lands to make arrests under federal law. However Indians are not subject to most state and local laws while on their reservation. Most tribes govern themselves through their tribal councils and governments. The shinnecock Indians of Long Island are an example of this.

\section{HISTORY}

When I first began this project, I was against gambling on Indian reservations. However, after extensive research and discussion with Indian people who have casinos on their reservations. I have come to the conclusion, that casinos on reservations have helped to uplift Indian communities across the country. The money that is made by these casinos, have helped to build homes, schools, and to create jobs for Indian people. Therefore, I believe that casinos are a positive for Indian people. I also think that hey are an integral part in the growth of Indian communities in the United states.

When the first European settlers arrived in this land, now called the United States, they were surprised 


\section{U.R.I. LIBRARY SPECIAL COLLECTIONS}

to learn that Indian tribes operated under unwritten laws that pre-dated the written history of the European culture; also they were surprised to find that the "Indians" were sophisticated and human enough to gamble. "Gambling figures equally in the traditional cultures of modern times. The British psychologist John Cohen, using material recorded by the Bureau of American Ethnology in the time of John Wesley Powell, remarked with apparent astonishment that American Indians were avid gamblers."4

Their games were very much like European games and other games in traditional cultures. "Their Games, (like the English) were of two sorts; Private and publike: Private, and sometimes Publike; A game like unto the English cards; yet, in stead of Cards they play with strong Rushes. Secondly, they have a kinde of dice which are plumb stones painted, which they cast in a Tray, with a mighty noysy and sweating; Their publique games are also solemnized with the meeting of hundreds: sometimes thousands..."5

Gambling was acceptable at the time of early contact with Europeans in the $1600^{\prime} \mathrm{s}$. It was also inviting because it provided Indians with the possibility and potential to acquire trade money (which was wampum) and barter for goods. Narragansett Indians had practiced gambling before their contact with Europeans. It was an acceptable part of society and played an important part in the distribution and redistribution of goods and wealth in their society. 
According to Roger Williams, "Keesaqunnamun, another kinde of solemne publik meeting, wherein they lie under the trees, in a kinde of religious observation, and have a mixture of devotions and sports: But their chiefest idoll of all for sport and game is (if their land be at peace) toward harvest, when they set up a long-house called Qunnekamuck. Which signifies long-house, sometimes in hundred sometimes two hundred foot long upon a plaine neer the court (which they call Kittcickauick) where many thousands of men and women meet, where he that goes and danceth in sight of all the rest; and is prepared with money, coats, small breeches, knifes, or what hee is able to reach to, and gives these things away to the poore, who yet must particularly beg and say, Cowequetummous, that is, I beseech you: which word (although there's not one common beggar amongst them) yet they will often use when their richest amongst them would fain obtain ought by gift."6 There were special long-houses made strictly for it. A large wigwam or a long-house was used to gamble in. Surplus wampum was stored at the gambling arbor. There was a word for the playing arbor which was Puttuckquapuonk. Dice, cards, betting on football games (a form of soccer) was all a part of the Indian warrior and hunters' social life. According to Roger Williams in 1634, "This arbour or play house is made of long poles set in the earth, four square, sixteen or twenty foot high, on which they hang great store of their stringed money, have great 
stakings, towne against towne, and two chosen out of the rest by course to play the game at this kinde of dice in the midst of all their Abettors, with the great shouting and solemity: beside they have great meetings of football playing, onely in summer, towne against towne."7

The colonial and the succeeding United states laws made by Euro-Americans, forced Native Americans to acknowledge these laws since the establishment of this country beginning in the mid $1600^{\prime} \mathrm{s}$. The colonial founders tried to create what they thought was a better system. Many were disgusted with the Church of England which governed the people. This was the remarkable thing that Roger Williams was noted for, he was able to separate religion and the government. Unfortunately for the Indian people, the very issues the Puritans thought were unfair and caused their banishment and distress, were the same issues and treatment they ended up imposing on the Indians. According to Russell, "Puritans called the practices of the Indian Pow-Wow diabolical even while praising their success with bone set, wounds made whole, the ill recovered. Indeed after acknowledging the native doctors' skill, Gookin remarks that; they are reported and I believe justly, to hold familiarity with the devil and therefore are by the English laws prohibited from the exercise of their diabolical practices."8 All non-Indian governments in the United States from colonial times to the present have first tried to change the religion, social habits 
such as gambling, and eventually every aspect of Indian culture. Should laws, which Indians should not have to practice, govern and control their new found economic freedom gotten from gambling? Should Indians willingly allow themselves to be governed by white lawmakers who discriminated against them, lied to them, and treated them unjustly? According to Richard Sasuly, "And again violence for hire has figured in the U.S. industrial history practically from the beginning of the republic. In fur trapping, after the speculators lobby did away with the reasonably humane factory system, violence against Indians was the key to the trade."9

our existing government was founded on hypocrisy in the sense of the American Indian. Indians gave up their freedom in order to free others. This is why whites came to the new world at such a rapid pace to start a new life for their families. The Indian government was a strong spiritual government. The church did not have to influence the king, who influenced the Parliament. The unique and successful feature of Indian politics is combining religion, politics, and a universal Indian world view, without the violence and fear which accompanied the Puritan combination. There was not a need to separate the two. The religion kept them genuine, not corrupt, it never needed reforms for this reason. There was a strong need in European society to separate the two because it was so corrupt. Edmund s. Morgan, a colonial historian states: 10 
"Although the most eager English reformers, the Puritans combined their tributes to the Queen with detailed instructions about the proper way to play her destined role, Elizabeth ignored them and took no steps to eradicate the visible remains of Roman corruption that the Puritans, pointed out to her in the Church of England. By the time her successor took the throne and began to talk about harrying the Puritans..."10

The coercive assimilation period (1880 - 1930) was a brutal time for Indians. A recurrent issue in the development of public opinion and attitudes towards American Indians was the issue of assimilation. In the 19th century, a considerable number of people believed that Indians were incapable of handling their own economics because they were intellectually and morally incapable of learning Euro-American culture. Indians were literally and physically beaten to conform to Euro-American culture by means of Christianity. Coercive assimilation did not always mean brutal force, it did include psychological abuse. It was the moral equivalent of racial discrimination. In this country Indians were morally committed to the value of the individual human being; both the discrimination and forced or coercive assimilation denied this to the individual who was on the receiving end. Psychologically, both were based on the ethnocentric intolerance of differences, on prejudice, or on ignorance. This history of coercive assimilation helps us to 
understand Indian and white controversies in the 1990's

over Indian casinos. Positioned to face Donald Trump, who is potentially armed with a war chest worth several billion dollars, Indian gaming tribes prepared to defend themselves against the onslaught of people who were against Indian gaming. Their opponents would wage a campaign against tribal gaming in the 103rd United states Congress in 1994. Many tribes, including the Narragansetts, were seeking to establish an economic base through gaming and are intimately familiar with the arguments being waged against gaming.

In November 1993 several tribal governments, including members of the Narragansett Indian Tribal Council, said it was the intent or the practice of the tribes with casinos to use gaming revenues to battle unemployment rates as high as 97 percent. The Sioux tribe of South Dakota is a example of how Indian Gaming has helped the job market for reservation Indians and their communities. The Indian Gaming Regulatory Act mandates that without a Secretarial waiver, tribes must receive at least 70 percent of profits from their casinos. "Tribal gaming profits were directly benefiting Indian people by providing them with schools, houses, clinics, and convenience stores", according to a Narragansett Councilman.11 The list of benefits was long and several successfully eradicated unemployment. The Mashantucket-Pequots of Connecticut were another example of how casinos have worked 12 
well for Indians. The non-Indian community also benefited with jobs, tax revenues, industry, and charitable contributions from casinos. On July 27, 1992, the House of Representatives passed H.R.4004, the Indian Tribal Justice Act of 1992.12 on July 16, 1992, the senate select Committee marked up and voted out of Committee, S.1752, The Indian Tribal Courts Acts of 1992 with comments by senator slade Gorton (R-WA), indicating that while he believed there were a "good things" in S.1752, he intended to attempt an amendment to the bill on the senate floor.13 This was significant because if the Indian reservation and/or tribes were operating or governing with a "makeshift" government and had implemented a structure which had been successful in building schools, health-care facilities and the like, then what did that say about the United States own federal and local governments that were in place? The Federal Government should not be able to control or take care of Indian people forever. Therefore, the government should give the Indian people a chance to prosper on their own. They were doing the best that they could to survive. With all that has happened to Indian people at the hands of the Federal Government, if casinos could help Indians, why not? The federal government could barely handle its own affairs.

SHOULD INDIANS TURN OVER THEIR GOVERNMENT TO A GOVERNMENT WHICH HAS HISTORICALLY TREATED THEM UNFAIRLY? 
A Mohawk elder said, "Throughout Indian country, Indian governments were being hustled by gaming experts, consultants and attorneys into bingo, card houses, casino gambling and various forms of gaming schemes that would "make them wealthy". In some areas of the United states, some Indian governments were very successful."14 However, that is not necessarily how the media, federal government, or some local governments have depicted the Indians' governments separately or as a whole. But, "the other side of the story too often shows that gaming operations have destabilized Indian governments, produced no monetary benefits for the tribes, and created false expectations of these people, soon the Indian experts, consultants and lawyers got on the bandwagon with some results. Tribes were accused by the news media, 20/20, CNN, Jack Anderson, and others as incompetent to manage their own affairs and victims in need of protection. This same media refused to tell the whole story, focusing instead on stale but sensational stories. The de ja vu feeling is strong at this point and Indians must flinch ideologically, recalling past 'protective' actions of the U.S. government on the Indians' behalf."15

The reasonable deduction is this: major premise: Indians are being subjected to temptations (they are making or have too much money), minor premise; we, (USA) have a duty to protect Indians from evil. Conclusion: therefore, Indians' money will be taken away. Or, here Indian, have 14 
a drink, oh well you're drunk, now give me your money. This cycle of American history shows how many Indians were forced to assimilate in the name of economic development for white society, and that bingo, gaming, and gambling wars were only one small battle in the wars that had gone on for centuries. Indians had to be, must be, and will always have to be careful about assimilation, whether it is education, economic development, religion, attitudes, or iron pots. The consequences are too great to ignore. Indian people must be patient, they must invest their money wisely from their casino earnings, if Indian people can do that their potential for long term financial stability will only increase.

A one time archaeology professor at Rhode Island College, Dr. Peter Pagaulotous, explained it this way, "Indians must remember the political roller coaster that the federal government has had them on for centuries. There were different phases which were representative of different attitudes and economic motives of the federal government. There was the separation, coercive assimilation, tribal restoration, termination, tribal reinstatement, and federal detachment."16

It began with the Separation Phase I (1760 - 1880), a time span when Indians were encouraged to be separated from white society. This was a ploy to separate Indians from their resource-rich valuable lands. $\frac{\text { Coercive Assimilation Phase II }}{15}(1880-1930)$. The 

of another. However, it is certainly the first time in the history of Native American and European occupation of the United States that Indians finally have hope. In no other century, since the arrival of Europeans, have Indians had hope for the Indian race, for the future generations, and for economic sovereignty.

Federal detachment must take place or Indians will cease to exist as Indians. According to Billy Whitemountain, a Passamaquoddy/Cree, "Indians are the true keepers of life because they alone possess the wisdom which the three major religions (Judaism, Christianity and Islam) have forgot. Without Mother Earth we can not survive, the Creator is going to avenge the mistreatment of the Red man and it is beginning with the casinos now."17 The casinos are a part of the brighter future Indians have been waiting centuries for. With the money generated, they now have hope for building their future.

\section{ARE INDIANS MAKING MONEY FROM INDIAN OWNED GAMING}

\section{FACILITIES?}

The Mashantucket-Pequot Tribe has publicly reported its slot machine revenues because the Foxwoods Casino in Ledyard, Connecticut was obligated to pay $25 \%$ of its gross slot win to connecticut. Its table game revenue has always been a guess. But when G. Michael Brown, President and CEO of Foxwoods, responded to a question before a Congressional panel, he let out the figures that 


\section{U.R.I. LBBRAPY SPECIAL COLLECTIONS}

Foxwood earned in 1992.18

Brown said that Foxwoods had been averaging casino earnings for both tables and slots of over $\$ 1.6$ million a day. Since the casino added another $46,000 \mathrm{sq}$. ft. in September 1993 gamblers spent over $\$ 4.4$ million a day on Foxwood's slots and tables. This figure translated to a monthly win of almost $\$ 50$ million, and $\$ 600$ million for the year.19

Although the Mashantucket-Pequots seemed to be faring well, other tribes with casinos seemed to take in less. Tribes in Iowa distributed profits in 1993 of over $\$ 5.7$ million in casino earnings and money was given to two specific reservation. About 7,000 enrolled members of the Omaha Indians, which operate their casino near the Nebraska border, received about $\$ 500$ each.20 Also, the 3700 members of the winnebago tribes each received a check for $\$ 6000$. The Winnebagos operate the Winne Vegas Casino, 20 miles north of Casino Omaha. The reason these tribes were getting this money was because of the Indian Gaming Regulatory Act of 1988, which allowed for 20 percent of the projected 3 year revenues from Indian Casinos to be distributed equally to the tribal members.21

Many projects to benefit Indians were created from gaming proceeds. Indian communities have been able to develop their own community centers, housing, new roads, water towers, treatment plants, new clinics, and office buildings.22 The San Manuel Band of Indians of Highland, 
California, had 75 percent unemployment, poor health

\section{U.R.I. LBBRARY SPECIAL COLLETIONS}

programs, and no educational opportunities prior to 1986 . Prior to the establishment of their gambling facility, the tribe, was unable to address important health and welfare needs of their tribal members. "Today, over 90 percent of the tribe is employed," said Norman Manzano, a tribal chairperson. "Gambling has allowed us to offer our people health-care higher education and housing. This tribe now has hope for the future."23 since the sycuan Tribe of Hollywood Park, California began operation in 1983, it became the largest gambling facility in the state and one of the most successful in the U.S. The casino, the church, the child-care center, library, and new homes of tribal members were all made possible by revenue from its gaming facilities. Sycuan Casino General Manager Rick LaBrake stated, "Our gambling operation has allowed the tribe to close some doors. We have left behind years of poverty and times when no doctors would come to the reservations to care for those who were ill. We have closed the doors on welfare dependents and have become economically self-sufficient." 24

DID NON-INDIANS MAKE MONEY FROM INDIAN OWNED CASINOS IN THE 1980's AND 1990's?

Millions of dollars were made annually by non-Indians. For example, in late July of 1993, the San Manuel Band of Indians in Highland, California, reported that their 
bingo operation spent $\$ 8$ million annually in the local area for goods, services and wages. The Bingo Hall payroll exceeded $\$ 2.2$ million annually. In addition, the tribe made direct payments of more than $\$ 1$ million to the county of San Bernardino to mitigate any impact on local governments. 25

The Mashantucket-Pequot Tribe had a five-year contract with three neighboring towns in Connecticut. These towns were Ledyard, North Stonington, and Preston. The Tribe agreed to pay $\$ 5$ million to these towns over the course of five years. During the first full fiscal year, 1993-1994, the state was guaranteed no less than $\$ 100$ million dollars from the Pequots. Sixty percent of the money went to the state's poorest neighborhoods, which were not Indian communities.

The Mashantucket-Pequot Tribe had its own fire station, ambulances, clinic, preschool and recreation areas. They also built an archaeological research center, new administrative offices, an Indian cultural center, and a museum. All of these were equal opportunity establishments that employed non-Indians, as well as Indians. Money made outside of the Foxwood Complex was hard to determine because actual figures had not been released. Millions of dollars were spent on the construction of a resort, the salaries of employees, and a variety of expenses that went outside the community. The statistics show that Foxwood's remarkable facility 20 
took in a monthly revenue of $\$ 50$ million, making it the highest grossing casino in the nation. According to the Providence Journal on September 4, 1993. "The Foxwood Casino became the largest casino complex in the western Hemisphere."26 The addition of a hotel, numerous restaurants, and a swimming facility made this true.

WHAT ARE THE INDIANS DOING WITH THE PROFITS?

In 1994, the Mashantucket-Pequot Tribe was building a high technology $\$ 100$ million dollar museum. It was to recreate the pastoral New England life prior to the arrival of the Europeans. The museum was located a half mile from the casino. A monorail train was being built to transport people back and forth from the casino to the museum. The majority of reservations with casinos built schools, medical facilities, and homes. In 21 years an organization called the Public Gaming Research Institute had 90 conferences and exhibitions in response to crucial educational needs. Ninety-five of all Indian-owned casinos contributed to schools either directly or indirectly. The following news caption was common. "The School that Indian Gambling Built." The ICS, the city's only elementary school for Indians children, and Milwaukee's Potawatami Bingo Hall, one of the nation's largest Indian Gaming facilities, formed a unique alliance dedicated to providing Native American young-people in the Midwest Industrial hub with a good education balanced with an awareness of 21 
their cultural heritage. They spent $\$ 1$ million on

\section{U.R.I. LIBRARY SPECIAL COLLECTIONS} renovations with the funds made by the Potawatomi Bingo.27 Income from gaming permitted the construction of a kindergarten, an eighth grade classroom, and a cafeteria. The Public Gaming Research Institute sponsored research for other institutions' studies and data on the process and effects of education. The Public Gaming Research Institute encouraged Indian communities to build or expand on their educational centers. 28

Indian casino gambling was negotiated between Indians and the federal government, and was put into place to give Indian people economic sovereignty. Gambling on Indian reservations was a way for Indian people to have a better opportunity to make it in the whiteman's society. The greatest accomplishment would be to give a bright future to their children. According to Nancy Brown-Garcia a Narragansett Indian educator from Rhode Island, "It has always been a common practice of Southern New England Tribes and most of all the other tribes, to want a brighter future for their most valuable possession: their children. Narragansetts deal with issues carefully because we want to educate our children. It is essential that our children get a good education because they will be the future keepers of the ancestors' sacred 


\section{U.R.I. LIBRARY SPECIAL COLLECTIONS}

grounds, the overseers of future generations, and the future of the tribe. We can not rely on the BIA (Bureau of Indian Affairs) to look out for our best interests, we must do it ourselves. When the economy drops Indian social welfare programs suffer. Health-care, school, the elderly, and other social programs are cut or abolished. We only need casinos because it helps to fill the void in our cultural feature called distribution. European society destroyed or outlawed our means of distribution. Whether it was Nikommo, Potlatch, or Sun Dances. The Indian culture has been able to find balance with gambling and social welfare. Unlike the Euro-American culture we build. No money goes back into society in the white man's world. It goes into some white Republican's pocket, with a tax break to go with it. Whereas in Indian culture we build schools, clinics, and cultural centers. As long as Indians don't get greedy, then they will be able to prosper from gaming. But even if or when there aren't any gaming facilities Indians are and will prosper in one way or another. It is their time to prevail. Progress doesn't always show itself in the form of dollar bills."29

Not everyone believed that gambling was the answer to the Indian peoples' long term financial problems. From the President of the United States to the leaders of dozens of tribes, people had doubts.

In 1993, the President, Bill Clinton said that: "The Indian Reservations have been kept dependent for too long 23 


\section{U.R.J. LIBRARY SPECIAL COLLCTIONS}

and suffered from the paternalistic attitude of the federal government. They have never been empowered to seize control of their own destiny. And I do not blame the tribes for wanting to maximize possible flexibility on gambling. But what I'd like to see is a whole range of different initiatives so we can have real long-term economic prosperity because there is a limit to how much gambling the country can absorb. There is a limit to how many Las Vegas' can be successful, so we need to talk about it. And I would be happy to see some tribal leaders about it." 30

Like clinton, some Indians had doubts and fears about what Indian gaming had to offer for the long term. In the 1980's and 1990's issues on gaming casinos on Indian reservations was a major topic of discussion throughout Indian country. There was a division between Indian people who were for and those who were against gambling on Indian reservations. The Indians who were pro casino argued that the casinos supplied jobs and economic stability to reservation Indians. In contrast, the anti-casino Indians argued that the casinos brought greed and a lack of traditional focus. Some Indians believed the money generated would help their children toward a better education. Yet others thought the money would hurt the children.

Vera Kingbird, a Lakota woman from Minnesota stated, "I believe that casinos on reservations are a way for 24 
the federal government to take away the sovereign status of the nations where casinos are located. Too many things have to be compromised in order for casinos to be fully functional on Indian reservations. Yes, it is true that the tribes are making millions of dollars, but if Indian people lose sight of their traditional values and customs, then is it really worth the children suffering?"31

Paula Bess, a Shinnecock woman from Long Island, said, "Casinos are bringing financial gains as well as jobs to the reservations that have them. However, at the risk of losing the traditional aspects of life, casinos are not worth it. It is too bad that the government which is part of the problem, has not come up with better alternatives to help improve the conditions of Indians living on reservations."32

Jonathan Windy Boy, a Chippewa Cree from Rocky Boy Montana, said, "Casinos will eventually cancel each other out. The industry will become saturated and the economic gain will start to decrease. There are too many reservations within the same areas opening large-scale casino operations. Many Indian casinos are going to find themselves filing for bankruptcy. They are also going to find themselves relying on loans to pay back their debts." 33

Joey Carter, a Mashantucket-Pequot from Ledyard, Connecticut explained, "the casino has allowed us to educate our children. 
We're looking toward the future of our tribe and you can't succeed without education." 34

MORE INDIANS FINISHING COLLEGE

The number of Native Americans who attended and finished college is up, according to a new report by the American Council on Education. The report stated that a 103,000 Native Americans enrolled in college in 1990, $11 \%$ more than in 1988. However, Native Americans accounted for fewer than 18 of all college students. The report also mentioned that $53 \%$ of Native Americans who entered college left after the first year.35 This percentage remained steady over the years. The reason Indians left was because there was no support network or cultural relativity at the campus' where they were. Although the National Advisory Council on Indian Education was originally established by Public Law 92-318 of the Indian Education Act of 1972 , it was Indian gaming which contributed to the rise in the number of college graduates. The National Advisory Council on Education identifies retention as its primary initiative for 1994. Their target was to also promote the idea that the federal government should continue to pay for Indian education and to free monies from casinos. This was promoted and identified because leading Indian educators believed that Indian education was a federal 'entitlement' paid for many times by the Indian Nations with billions of acres of Indian 
lands ceded to the United States. National Advisory Council Chairman Whitebird stated, "We want to pursue this initiative with the utmost effort."36 Indian monies are being spent to provide and encourage Indian youth to get an education. It would not be as possible and as wide spread without the aid of monies from the casinos. According to Terry R. Stanton-Brown B.A. of the Narragansett Indian Tribe, "The reason for fewer Native Americans in college is due to the lack of financial resources that are available. If you are a Native American trying to seek an education, you must compete with thousands of other Native Americans in the United States and Canada for scholarships and grants. When the thousands of scholarships and grants are given out, the remainder of students must either pay their tuition themselves or hope for federal assistance. Another reason for the high drop out rate in college is because there are few programs in place to give the Indian students support."37 How else would tribes pay for all of their students without monies from casinos? Tribes would be forced to totally rely on the federal government.

\section{A NARRAGANSETT PROPHECY RETOLD}

According to Max Brown a Narragansett elder, "An old New England Sachem told of a time when the white man's greed, which is why the Indians way of traditional life was terminated, would be the very thing that comes back 27 
to rebuild Indian Nations. He also said that we "the Red Man" would know when because the earth will appear to be mad or send warnings to the red race. He warned not to join the white man but to benefit from his greed. Some elders and leaders are telling tribes to profit from the gaming but not too get greedy. And the Hopi agree and have legends and prophecies too. It is significant what the Hopi and Navajo feel because Indians believe that life sprung up from the southwest. These people hold much of the spiritual prophecies for all Indians."38

\section{A HOPI PROPHECY RETOLD}

The prominent Thomas Banyanca, a well known Native American leader, stated at the General Assembly at the United Nations in a private session in 1993, "That his people had a centuries old prophecy which told of a time when the Hopi people were to address the world leaders 'in a house made of mica (glass).' Banyanca had made three other attempts to speak to the general assembly but the forces of nature prohibited him; on his forth and successful attempt, he warned the national representatives in the assembly that 'Human beings are destroying our sacred mother earth in pursuit of money and greed.' He told of the "third world shaking' that will cleans the earth by floods, fire, earthquakes, volcanic eruptions, drought, famine, war, and pestilence.' Outside the glass house in which Banyanca spoke, 90-mile-per-hour winds 

entrepreneur/developer, sued Interior Secretary Bruce Babbitt and Tony Hope, chairman of the National Indian Gaming Commission. The civil lawsuit argued that the Indian Gaming Regulatory Act of 1988 also mandated states to authorize Indian gambling operations, stripping the states of their "sovereign, constitutional powers to tax, regulate and police gambling activities conducted within their borders." 42 The lawsuit was filed on $6 / 93$ in U.S. District court. It argued that federal commandeering of the states to implement an essentially unregulated federal program violated the Tenth Amendment.43 An attorney for Trump, John Barry said, "the lawsuit is not seeking to ban Indian gambling, but rather that states be granted the power to accept or reject Indian gambling operations within their borders." 44 when discussing the states that have been affected by the Indian Gaming Act, the Ramapough Indians of northern New Jersey and New York are mentioned. The lawsuit sites the Ramapough Indians in its discussion of states that have benefited by the Indian Gaming Act. The Ramapoughs are one of many tribes trying to get federal recognition from Babbitt and the commission, a preliminary step towards entering a gambling agreement within the state of New Jersey. George Schneider the Ramapough Indians' lawyer said of Trump, "This guy is unbelievable, his father hands him a multi-million-dollar empire. The Native Americans are lucky if they can give their children food, clothing and a roof over their heads," schneider 30 
represents over 2000 Ramapoughs. He went on to say that Trump was being greedy. "He can not accept the potential honest competition that Native Americans may present to his casino empire." 45 when the news of Trump's suit was made public there were many people who expressed their opinions Michael Anderson, Executive director of the National Congress of American Indians, was quoted in USA TODAY, saying Trump "should stick to the details of his prenuptual agreement with Marla Maples and avoid the difficult questions of Indian gambling, of which his lawsuit demonstrates he has no understanding."46 According to USA Today, Trump's empire of gambling, which includes Trump Plaza Hotel and Casino, Trump's Castle Casino Resort, and Trump Taj Mahal Casino Resort located in Atlantic City, earned an estimated gross revenue of \$920 million in 1992.47 The National Indian Gaming Association, on the other hand, recognizes 85 Native American Tribes with 16 casinos sites in 18 states, with a 1992 gross revenue estimated at $\$ 6$ billion. It was very clear that even though these figures were gross earnings, Indian people make significantly less money than Trump. The reason was because Indians had to split their casino profits with a large number of people; therefore the money being made by Indian casinos was not as much as people thought. Trump's individual income was far superior to what any Indian tribe could make by itself or grouped together with other casino tribes. Indian Gambling 
officials believed that Trumps' tactics are because of envy and greed. Observers of his actions say that Trump feels he is losing money because of the new presence of casinos on Indian reservations.

According to the st. petersburg Times, "At the heart of Donald Trump's latest foray into the news is not a question of whether the gaming act gives states enough freedom to regulate Indian gambling operations effectively, including lucrative bingo halls, and not the question of their fair treatment. The issue is greed, and it apparently has clouded Trump's understanding of the devastating history of Native Americans and the government's inadequate attempts to compensate. Before he tries to crack down on competition, the least Donald Trump could do is crack open a history book." 48

Donald Trump is not the only one opposing Indian gaming. The State of Rhode Island has tried to prohibit the Narragansett Indian Tribe from building a casino. The Federal Appeals Court ruled on March 23, 1994 that the Narragansetts have the right to build a casino. The Mooreheads, a white married couple who reside in Rhode Island, who support the Narragansetts in their pursuit to build a casino on their reservation said, "The state of Rhode Island, everytime they get their fingers in something, they make a mess of it. Just look at the state lottery, they said that when they passed that they would do away with the sales taxes and that never happened. 32 
The Mooreheads think it is unlikely that a Narragansett casino would grow into a megaplex like Foxwoods. "They've missed the chance, the state has horsed them around for so long, that the opportunity is gone."49

SHOULD INDIANS FIGHT AGAINST THE GOVERNMENT WHICH HAS NOT LOOKED OUT FOR THEIR BEST FINANCIAL INTEREST?

During the Bush Administration, issues of Indian sovereignty heated up. On December 16,1987 , more than 230 New York State Police and F.B.I officers raided Akwesasne and removed 239 slot machines from the Bears Den on the Mohawk Reservation. Owner Eli Tarbell unsuccessfully appealed to the office of Governor Mario Cuomo for negotiations to legalize gaming on the Mohawk land. Under the Bush administration's urging, the New York State Police and Federal Bureau of Investigation officers planned elaborate raids on casino owners on federal gambling charges. The negativity was still present in 1992. Headlines read on Wednesday, May 13, 1992: "F.B.I. Agents Raid Casinos on 5 Indian Reservations." Acting on days old government rulings, 5 casinos across Arizona were raided. One reservation casino at Ft. Mc Dowell brought in about $\$ 19$ million in five months and about $80 \%$ was from the machines which were removed.50 Indian leaders were outraged because income and revenues from casinos help social programs on their reservations. National Indian leaders were asserting that tribes are 

against the mob,"52 Trump went on to say later. However, these allegations were disputed by Jim Moody, section chief of the FBI's organized crime division, who acknowledged that "organized crime interests go after money, but there is no evidence that the mafia is using reservations to launder money, exert threats, or skim illegal income off gaming operations."53 Rita Keshena, attorney of the Lac Du Flambeau stated, "Make no mistake. It is not some finite principal, some moral judgment that organized crime is going to be infiltrating us. It's money. If Pow-Wows made as much as rock concerts, there would be a National Pow-Wow Act. They would be regulating it because money would be coming to the tribes."54 Rick Hill, the chairman of the National Indian Gaming Association said, "There's no organized crime or disorganized crime on Indian reservations... what critics of Indian gaming are really afraid of is organized Indians."55 If organized crime was involved with Indian casinos it was not known by the FBI, or the National Indian Gaming Association.

GAMING HAS ENABLED TRIBES TO MAINTAIN TRADITIONAL AND CULTURAL IDENTITY

Capital from Indian gaming has enabled tribes to hold events and build institutions that have helped its members maintain their traditional and cultural identity. The Mashantucket-Pequots, for instance, have used proceeds from their casino to build a recreational center 35 
where they often hold cultural events including winter socials. One, in March of 1994, drew hundreds of Indians from the northeastern United states and Canada who came to dance and sing. In september 1993, they put on a Pow-Wow at the Hartford Civic Center that had $\$ 200,000$ in prize money for dancing and singing. The event attracted over 25,000 Indians. "We're helping out just by being here," said Tomme Roubideaux, a Lakota from Saskatchewan who is pursuing a doctorate in social work at Washington University in st. Louis. "Some of us are not here to go for the prize money, but just to show that there's a presence and that they have support. Political support and social support from all the tribes in the country."56 The Mashantuckets hold cultural classes each week to teach tribal members traditional dances. This shows that the revenues from their casino has helped them to network with other tribes and to create facilities to help them bring cultural awareness to their people as well as other tribes.

Wayne Duncan, a Cherokee man from Long Island said, "Indian casinos have created a way for tribes to build up their communities and self-esteem as people. I do not see anything wrong with tribes prospering from casino revenues. I do not understand why people are trying to make problems for Indian reservations that have casinos. I never heard much about casinos until Indians got involved. It seems that because Indians are making money 36 
people are complaining. There is a double standard when it comes to Indians."57

\section{CONCLUSION}

Indian people must preserve Indian gaming. Words can be powerful weapons in this struggle. Tribes can no longer worry about the large commercial gaming interests who put down the Indians' smaller market gaming. Tribes must go on with their dreams and aspirations of a brighter future for their people. It is true that many people like Trump are using racist and unfair tactics to deter Indians from gambling. These people are jealous and would do or say anything to hurt Indian people. However Indians must not let these ignorant people stand in their way. Indian people must communicate what Indian gaming has done for the masses of Indians who were in poverty, such as create jobs and build homes.

Another important aspect is the rise of the states' overall economies that have Tribal gaming operations. The people who visit the Indian casinos spend money in the towns where the casinos are located. It must be proven to policy makers, jurists, and voters, that Indian casinos decrease the number of people on welfare and how Indians as well as non-Indians are benefiting from the revenues. As far as compulsive gamblers go, I believe that people have the ability to make decisions for themselves. If people decide to spend their money on gambling that 
is their choice. Information should be gathered on these specific impacts of Indian gaming. The reservations as well as the towns, counties, and states are all receiving profits.

There is also the issue of how Indian people are getting some of their lost pride back. Gambling has provided Indians on reservations with experience, educational facilities, and their first chance at self-sufficiency will put Indians from non-casino reservations in a position to earn money as well. Indians from non-casino reservations across the country are able to find good jobs on reservations with casinos. The profits from Indian Gambling have allowed tribes to govern as more sovereign nations. Indian people finally have the means to improve the quality of life for their people. Indian people need to come together and work out their differences. This will in effect make the tribes stronger in their quest for harmony and financial stability. The struggle for Indians to preserve Indian gaming is imperative. Gambling is the only economic means that has worked for Indian people on a large scale since their land and resources were taken away in the 19 th century. Indian people must gather information to tell their side of the story. The winners of. wars of the past and present write the history of our country. It is up to Indians to make sure that their side of the story is told. When this happens hopefully people will have a better 38 
understanding of the Indian struggle to survive and why gaming is so important. 
ENDNOTES

1. The Providence Journal, March 24, 1994, p. 1 .

2. Ibid., 1 .

3. Indian Law Documents, September 5, 1988, p. 7 .

4. Richard Sasuly, Bookies \& Bettors: 200 Years of

Gambling. (New York: Holt, Rinehart and Winston, 1992), pg. 42 .

5. Roger Williams, Key into the Language of America.

(London: Printed by Gregory Dexter,

1643 Reprinted Providence for the Rhode

Island and Providence Plantations

Tercentenary Committee, Inc., 1936),

pg. 177 .

6. Ibid., 180 .

7. Ibid., 179 .

8. Howard Russell, Indians of New England Befor the

Mayflower. (New Hampshire: University

Press of New England, 1980), pg. 27.

9. Richard Sasuly, pg. 43 .

10. Edmund S. Morgan, Roger Williams: The Church and the

State. (Harcourt: Brace \& World, Inc., New York), pg. 9 .

11. Interview with Narragansett Tribal Councilman, His

Home, December 5, 1993.

12. NCAI SENTINEL, Vol. 56: No.2 August 1992, 


$$
\text { p. } 5 \text {. }
$$

13. Ibid., 5 .

14. AKWESASNE NOTES, Early Winter 1985, p. 5 .

15. Ibid. 23 .

16. Interview with Dr. Peter Pagalotous, University of

$$
\text { Massachusetts, March 5, } 1989 .
$$

17. Ibid., with Billy Whitemountain, Pequot Social, March

$$
11,1994
$$

18. Casino Journal, Vol. 6: No.9 November 1993,

$$
\text { p. } 60 \text {. }
$$

19. Ibid., 60 .

20. Casino Journal, Vol. 6: No.11 January 1994,

$$
\text { p. } 60 \text {. }
$$

21. Ibid., 60 .

22. Indian Gaming, December 1993, p. 18 .

23. Indian Gaming, August 1993, p. 18 .

24. Indian Gaming, December 1993, p. 27.

25. Indian Gaming, August 1993, p. 18.

26. The Providence Journal, September 4, 1993,

$$
\text { p. } 1 \text {. }
$$

27. Indian Gaming, June 1993, p. 25.

28. Ibid., 25 .

29. Interview with Nancy Brown-Garcia, Warwick,

$$
\text { R.I., March 28,1994 }
$$

30. Indian Gaming, June 1993, p. 18 .

31. Interview with Vera Kingbird, Pequot Social,

$$
\text { March 12, } 1994 .
$$


32. Ibid., with Paula Bess, Shinnecock Reservation, December 23, 1993 .

33. Ibid., with Jonathan Windyboy, Hartford Pow-Wow, September 17, 1993 .

34. EAGLE WING PRESS, Late Winter 1993.

35. Indian Gaming, June 1993, p. 26 .

36. Ibid., 26 .

37. Interview with Terry $R$. Stanton-Brown, Her

Home, April 4, 1994.

38. Ibid., with Max Brown, His Home, April 4, 1994.

39. Indian Gaming, June 1993, p. 26.

40. Interview with Paula Bess, Shinnecock Reservation,

December 23, 1993.

41. Indian Gaming, June 1993, p. 18 .

42. Ibid., 12 .

43. Ibid., "

44. Ibid.,"

45. Ibid.,"

46. Ibid.,"

47. Ibid.,"

48. Ibid.,"

49. The Providence Journal, March 24, 1994, p. 1 .

50. The New York Times, May 17, 1992, p. 18.

51. Ibid. , 18 .

52. News From Indian Country, October 1993.

53. USET GAMING, Vol. 1: No.1 Fall, 1993, p. 5.

54. Indian Gaming, December 1993, p. 8 . 



\section{BIBLIOGRAPHY}

Batra, Ravi. Regular Economic Cycles. New York: St. Martin's Press, 1985.

Hornung, Rick. One Nation Under the Gun: Inside the Mohawk

Civil War. New York: Pantheon Books Random House, Inc., 1991.

Johnston, David. Temples of Chance. New York: Bantam

Doubleday Dell Publishing Group, Inc., 1992.

Lester, Ivy, G. Tax Reform Act of 1987 Manuel. Chicago:

Longman Financial Publishing. Morgan, Edmund, S. Roger Williams: The Church and the

State. Harcourt: Brace \& World, Inc., New York. Murphy, Stephen. One Up on Trump: The 50 Million Real

Estate Baron. California: American Capital Foundation for the Homeless, Inc. 1993.

O'Donnell, J.R. Trumped! New York: Simon \& Schuster, 1991. Russell, Howard, S. Indians of New England Before the

Mayflower. New Hampshire: University Press of New England, 1980 .

Sasuly, Richard. Bookies \& Bettors: 200 Years of Gambling. New York: Holt, Rinehart and Winston, 1992. 
MAGAZINES

\author{
Casino Journal, (1993-1994) \\ Indian Gaming, (1992-1993) \\ NCAI SENTINEL, (1992) \\ USET GAMING, (1993)
}

NEWSPAPERS

AKWESASNE NOTES, Early Winter 1985, 23.

Eagle Wing Press, Early Winter 1993, 6 .

News from Indian Country, October 1993, 2.

The New York Times, 17 May. 1992, 18.

19 September. 1993, 52.

The Providence Journal, 4 September. 1993, 1.

24 March. 1994, 1. 
